\title{
Ekstrak Etanolik Hedyotis corymbosa L. Menurunkan Proliferasi Sel Pada Kelenjar Payudara Tikus Melalui Penekanan Ekspresi C-Myc
}

\author{
Ulfia Mutiara, Navista Sri Octa U., Fina Aryani Goenadi, Ratna Asmah Susidarti, dan \\ Edy Meiyanto
}

\author{
Cancer Chemoprevention Research Center \\ Fakultas Farmasi, Universitas Gadjah Mada, Yogyakarta \\ http://ccrc.farmasi.ugm.ac.id, \\ E-mail: meiyan_e@ugm.ac.id
}

\begin{abstract}
ABSTRAK
Kanker payudara menduduki peringkat kedua setelah kanker leher rahim yang menyerang wanita di seluruh dunia. Eksplorasi terhadap tumbuhan yang mudah ditemukan, seperti herba Hedyotis corymbosa, sebagai alternatif pengobatan kanker payudara perlu dilakukan. Dilakukan uji in vivo terhadap lima kelompok tikus Galur Sprague Dawley terdiri atas kelompok perlakuan DMBA (20 mg/kg BB), perlakuan ekstrak etanolik herba H. corymbosa (1500 mg/kg BB), perlakuan DMBA+dosis I (750 mg/kg BB), perlakuan DMBA+dosis II (1500 $\mathrm{mg} / \mathrm{kg} B B$ ) dan perlakuan pelarut CMC-Na 0.5\%. Kelompok perlakuan DMBA, DMBA+dosis I, dan DMBA+dosis II diinduksi DMBA 10 kali selama lima minggu. Kemudian setelah diistirahatkan selama empat minggu, dilakukan pemberian ekstrak selama 10 hari. Pada akhir percobaan dilakukan pengorbanan kemudian diambil jaringan payudara untuk diamati aktivitas proliferasinya. Dilakukan pengamatan imunohistokimia terhadap protein c-Myc pada jaringan payudara. Pengamatan pada metode imunohistokimia terhadap protein c-Myc menunjukkan adanya perubahan yang positif pada kelenjar payudara kelompok perlakuan DMBA+dosis I. Hasil yang diperoleh menunjukkan bahwa ekstrak etanolik herba H. corymbosa dosis $750 \mathrm{mg} /$ $\mathrm{kg}$ BB sudah mampu menghambat proliferasi sel kanker payudara dan tidak bersifat dose dependent.
\end{abstract}

Kata kunci : kanker payudara, Hedyotis corymbosa, proliferasi sel, c-Myc

\section{PENDAHULUAN}

Penelitian menunjukkan bahwa kasus kanker payudara merupakan kanker yang paling banyak diderita oleh wanita di seluruh dunia (Basu dkk, 2004). Peningkatan insidensi kanker payudara tidak diimbangi dengan kemoterapi yang efektif dan efisien. Kemoterapi merupakan salah satu langkah penyembuhan dalam kanker, telah banyak dilaporkan memiliki efek samping yang tidak menyenangkan, penyembuhan yang kurang tuntas bahkan terjadi resistensi obat. Oleh karena itu perlu adanya penelitian mengenai alternatif pengobatan kanker payudara yang efektif dan efisien berbasis bahan alam.

Indonesia merupakan negara yang memiliki plasma nutfah tumbuhan terbesar kedua di dunia setelah Brazil. Indonesia memiliki sekitar 3000 jenis tumbuhan obat akan tetapi yang baru diteliti hanya sekitar 500 jenis (Zuhud dan Haryanto, 1994). Plasma nutfah tersebut belum banyak dikembangkan sebagai bahan baku obat karena rendahnya penelitian yang dilakukan baik secara uji praklinik maupun klinik. Salah satu tanaman yang telah dikenal luas adalah herba Hedyotis corymbosa atau dikenal sebagai Rumput Mutiara dapat digunakan dalam kemoterapi kanker payudara..

Kandungan asam ursolat dalam herba ini dikenal memiliki potensi sebagai antiproliferasi sel. Penelitian yang dilakukan oleh Hsu dkk (2004) menunjukan hal yang 
tidak berbeda dimana ekstrak $H$. corymbosa potensial digunakan sebagai agen antiproliferasi sel. Berdasarkan penelitian secara in vitro yang dilakukan oleh Haryanti (2008) menunjukkan bahwa herba ini memiliki potensi sebagai agen kemoterapi yang dapat dikombinasikan dengan doksorubicin dan memiliki aktivitas sitotoksik pada sel MCF7 dengan $\mathrm{IC}_{50} 77 \mu \mathrm{g} /$ ml. Penelitian yang dilakukan oleh Mutiara, dkk (2008) juga menunjukkan bahwa ekstrak etanolik H.corymbosa kemungkinan mampu menghambat proliferasi sel dengan cara menghambat protein ERa. Penelusuran mekanisme penghambatan karsinogenesis ekstrak etanolik H.corymbosa penting untuk dilakukan.

Protein c-Myc merupakan faktor transkripsi onkogenik. Overekspresi c-Myc, yang disebabkan karena kerusakan genetik akibat dari amplifikasi gen atau kerusakan regulator, biasa ditemui pada kasus kanker. Protein ini berperan penting dalam meregulasi pola ekspresi gen, proliferasi sel, apoptosis dan proses diferensiasi (Amati dkk., 1998). Asam ursolat yang terkandung dalam herba H.corymbosa diduga memiliki mekanisme penekanan proliferasi sel. Hal ini mendasari pentingnya penelitian mengenai potensi asam ursolat sebagai agen antiproliferatif melalui penurunan ekspresi protein c-Myc dalam jaringan payudara.

Tujuan dalam penelitian ini adalah untuk mengetahui potensi ekstrak etanolik $H$. corymbosa sebagai agen antiproliferasi sel kanker payudara. Selain itu dapat diketahui kemungkinan mekanisme asam ursolat, senyawa aktif yang terkandung dalam herba $H$. corymbosa dalam menghambat karsinogenesis sel epitelial kelenjar payudara yang telah terinduksi DMBA. Penelitian ini diharapkan juga mampu menyingkap kemungkinan penghambatan ekspresi protein c-Myc, yang merupakan salah satu faktor transkripsi onkogen, oleh asam ursolat yang terkandung dalam herba $\mathrm{H}$. corymbosa.

\section{METODOLOGI}

\section{Determinasi Tanaman}

Sebagai langkah antisipasi terhadap kesalahan dalam penggunaan bahan baku maka perlu dilakukan determinasi tanaman di Laboratorium Farmakognosi, Bagian Biologi Farmasi Fakultas Farmasi UGM mengacu pada buku Flora of Java.

\section{Pembuatan Ekstrak Etanolik $H$. corymbosa}

Herba H.corymbosa yang diperoleh dari Kabupaten Sleman dikeringkan dengan menggunakan kain hitam hingga kering menurut standar yang telah ditetapkan sebelumnya. Simplisia kering kemudian diserbuk. Selanjutnya serbuk herba H.corymbosa dimaserasi menggunakan etanol $70 \%$ selama empat hari dan diremaserasi selama dua hari. Filtrat diuapkan dengan rotary vacuum evaporator.

\section{Pemeriksaan Kandungan Asam Ursolat}

Asam ursolat yang terkandung dalam ekstrak diperiksa menggunakan metode Kromatografi Lapis Tipis (KLT). Fase diam dipilih silica gel 60 F $254 \mathrm{~nm}$ dan campuran kloroform : etanol (9:1) sebagai fase gerak. Penampakan deteksi golongan senyawa dipilih asam sulfat $10 \%$ dalam etanol berdasarkan pertimbangan bahwa asam ursolat termasuk dalam triterpenoid pentasiklik.

\section{Uji In vivo}

Tikus betina galur Sprague Dawley berusia 40 hari dibagi dalam lima kelompok masing-masing enam ekor. Kelompok pertama kontrol 7,12 Dimetil Benz(a)Antarsen (DMBA) $20 \mathrm{mg} / \mathrm{kg} \mathrm{BB}$ dalam pelarut minyak jagung, kelompok kedua merupakan kontrol CMC-Na $0.5 \%$, kelompok ketiga adalah kontrol ekstrak etanolik H. corymbosa (1500 mg/kg BB), selanjutnya kelompok keempat diberi perlakuan DMBA dan ekstrak dosis I (750 $\mathrm{mg} / \mathrm{kg} \mathrm{BB}$ ) sedangkan kelompok terakhir diberi perlakuan DMBA dan ekstrak dosis II $(1500 \mathrm{mg} / \mathrm{kg} \mathrm{BB})$. Pemejanan DMBA dilakukan 10 kali selama lima minggu pada kelompok pertama, kelompok keempat dan kelompok kelima. Empat minggu kemudian, tikus dipejankan ekstrak etanolik $H$. corymbosa sebanyak 10 kali selama dua minggu. Langkah terakhir dalam penelitian ini adalah nekropsi jaringan payudara. Tikus dikorbankan dengan cara dislokasi leher. Selanjutnya payudara dibuat preparat jaringan untuk kemudian diamati dengan metode imunohistokimia. 


\section{Pengamatan Ekspresi Protein c-Myc}

Ekspresi protein c-Myc yang merupakan faktor transkripsi onkogen dapat diketahui dengan menggunakan metode imunohistokimia. Prinsip dasar metode ini adalah deteksi protein di jaringan berdasarkan ikatan antara antigen dan antibodi spesifik. Preparat diinkubasi dengan kromogen DAB $25^{\circ} \mathrm{C}$ selama 10 menit, diinkubasi dengan Hematoxylin Eosin selama 3 menit, kemudian dicuci dengan air mengalir.
Fakultas Farmasi UGM. Serbuk kering simplisia dengan bobot 500 gram diekstraksi dengan 3.5 liter cairan penyari sehingga diperoleh 70.5 gram ekstrak kental. Dalam proses ekstraksi ini diperoleh rendemen sebesar $14.1 \%$.

Kandungan senyawa aktif ekstrak etanolik $H$. corymbosa adalah asam ursolat dan asam oleanolat. Polaritas antara asam ursolat dan asam oleanolat nyaris tidak berbeda.

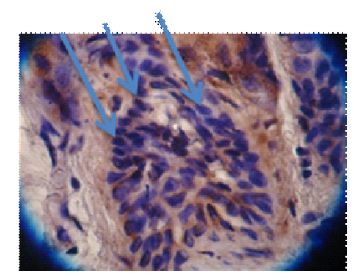

(A)

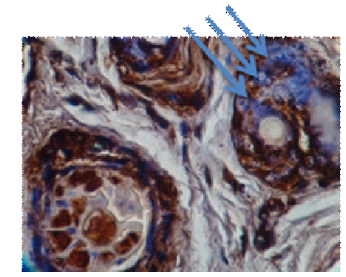

(B)

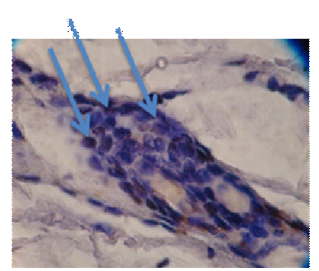

(C)

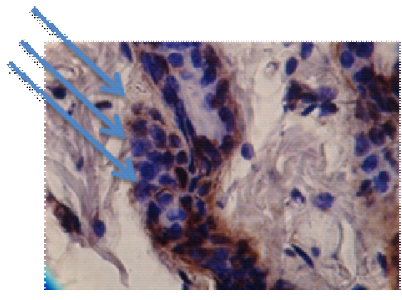

(D)

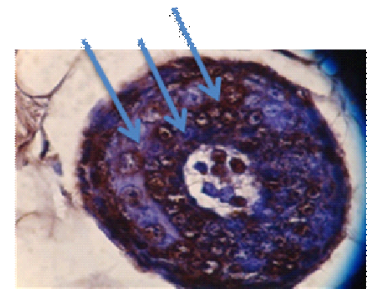

(E)

Gambar 1. Ekspresi protein c-Myc dengan metode Imunohistokimia. (A) perlakuan ekstrak Rumput Mutiara (B) perlakuan DMBA (C) perlakuan CMC-Na (D) perlakuan ekstrak $750 \mathrm{mg} / \mathrm{kgBB}$ (E) perlakuan ekstrak $1500 \mathrm{mg} / \mathrm{kgBB}$. Panah menunjukkan adanya dot hitam yang mengindikasikan adanya proliferasi sel

Preparat dibersihkan, ditetesi dengan mounting media, dan ditutup dengan coverslip kemudian diamat dengan bantuan mikroskop cahaya sehingga dapat terlihat dengan jelas warna sel. Sel yang mengekspresikan protein (c-Myc) akan berwarna coklat sedangkan sel yang tidak mengekspresikan protein akan berwarna biru keunguan. Pemeriksaan dilakukan dibawah mikroskop binokuler (OLYMPUS DP12 Microscope Digital Camera System) di laboratorium Parasitologi Fakultas Kedokteran UGM, Yogyakarta

\section{HASIL DAN PEMBAHASAN}

Hasil

Ekstraksi dan Pemeriksaan Kandungan Asam Ursolat

Herba dideterminasi di Laboratorium Farmakognosi bagian Biologi Farmasi
Deteksi senyawa asam ursolat yang ada dalam herba $H$. corymbosa menggunakan kromatografi lapis tipis dengan silica gel 60 F $254 \mathrm{~nm}$ sebagai fase diam dan kloroform : etanol (9:1) sebagai fase gerak. Pereaksi semprot asam sulfat $10 \%$ dalam etanol dipilih sebagai pereaksi semprot untuk deteksi golongan senyawa asam ursolat yang termasuk triterpenoid pentasiklik. Bercak berada pada hRf 65 dan berwarna merah muda pada pengamatan dibawah sinar UV $254 \mathrm{~nm}$ dan berwarna kuning dibawah sinar UV $366 \mathrm{~nm}$ baik pada asam ursolat isolat sebagai pembanding maupun pada sampel (data tidak ditunjukkan).

Imunohistokimia adalah metode yang digunakan untuk mengetahui keberadaan suatu protein di dalam sel. Prinsip metode pengecatan imunohistokimia adalah deteksi protein pada jaringan dengan 
menggunakan reaksi antigen-antibodi yang bersifat spesifik. Sel yang mengekspresikan protein (c-Myc) akan berwarna coklat sedangkan sel yang tidak mengekspresikan protein akan berwarna biru keunguan.

Dari hasil pengamatan tampak adanya ekspresi c-Myc yang tinggi pada kelompok DMBA, artinya terjadi peningkatan aktivitas proliferasi sel. Pada kelompok kontol ekstrak dan control CMC-Na tidak terlihat adanya peningkatan aktivitas proliferasi sel dan ekspresi protein c-Myc. Hasil pengamatan ekspresi c-Myc pada perlakuan dosis 1500 $\mathrm{mg} / \mathrm{kg}$ BB terlihat cukup tinggi dibanding kelompok perlakuan dosis $750 \mathrm{mg} / \mathrm{kg}$ BB. Hal ini menunjukkan bahwa kelompok perlakuan dosis $750 \mathrm{mg} / \mathrm{kg}$ BB sudah mampu menurunkan ekspresi protein c-Myc sebagai protein transkripsi sel.

Protein c-Myc merupakan faktor transkripsi onkogenik. Ekspresi c-Myc diregulasi oleh sinyal eksternal seperti faktor pertumbuhan. Protein ini berperan penting dalam meregulasi pola ekspresi gen, proliferasi sel, apoptosis dan proses diferensiasi (Amati dkk., 1998). Pada sel kanker, ekspresi c-Myc tidak terkontrol. Overekspresi ini disebabkan karena kerusakan genetik akibat dari amplifikasi gen atau kerusakan regulator (La Rosa dkk., 1994). Protein c-Myc dapat memacu proliferasi sel dan ketidakstabilan genetik melalui mekanisme percepatan sel melewati fase G1 dan S, mengabaikan checkpoint dan meningkatkan metabolisme sel. Siklus sel yang terjadi secara cepat menyebabkan repair DNA tidak dapat terjadi secara sempurna.

\section{Pembahasan}

Hasil uji in vivo menunjukkan bahwa ekstrak $H$. corymbosa mampu menghambat proliferasi sel epitel kelenjar payudara tikus galur Sprague Dawley terinduksi DMBA. Kemungkinan pemberian ekstrak $H$. corymbosa tidak bersifat dose dependent sehingga peningkatan dosis tidak sejalan dengan adanya peningkatan efek yang ditimbulkan. Berdasarkan hasil yang menunjukkan bahwa proses penghambatan proliferasi sel pada kelompok perlakuan dosis $750 \mathrm{mg} / \mathrm{kg}$ BB lebih baik daripada kelompok perlakuan dosis $1500 \mathrm{mg} / \mathrm{kg}$ BB. Penelitian yang dilakukan oleh Mutiara dkk (2008) secara in vivo dengan menggunakan metode AgNOR menunjukkan bahwa ekstrak H. corymbosa dosis $750 \mathrm{mg} / \mathrm{kg} \mathrm{BB}$ mampu menghambat proliferasi sel epitelial payudara yang teriduksi DMBA lebih baik daripada dosis $1500 \mathrm{mg} / \mathrm{kg}$ BB. Hasil pengamatan dengan metode HE (Mutiara dkk, 2008) mendukung hasil pengamatan dengan menggunakan metode imunohistokimia terhadap protein c-Myc.

Mekanisme antiproliferatif ekstrak $H$. corymbosa kemungkinan melalui penghambatan pada siklus sel. NF-êB, yang merupakan faktor transkripsi sel, berperan dalam proses kemoresistensi dengan cara aktivasi protein Myc sebagai perantara aktivasi transkripsi cyclin A dan D. Hal ini menyebabkan apoptosis terabaikan dan siklus sel terus berlanjut. Ekstrak $H$. corymbosa melalui downregulasi NF-êB akan menekan ekspresi protein antiapoptosis $\mathrm{Bcl}-2$ dan merangsang pelepasan sitokrom c, sehingga peristiwa apoptosis dapat berlanjut. Stimulasi NF-êB dapat melalui death receptors kemudian berinteraksi dengan gen target seperti IAPs dan menghambat jalur caspase (Schimmer, 2004); atau melalui sinyal proliferasi melewati jalur Akt sehingga mengakibatkan peningkatan ekspresi protein antiapoptosis (Haryanti, 2008). NFkB berkaitan dengan sintesis protein Cyclin D yang digunakan dalam persiapan pembelahan sel, artinya jika NFkB dihambat maka secara tak langsung sintesis protein untuk replikasi DNA ikut terhambat. Dalam hal ini yang berperan kemungkinan adalah asam ursolat karena kotribusi asam ursolat dalam aktivitas sitotoksik ekstrak $H$. corymbosa lebih dominan dibandingkan asam oleanolat pada perlakuan terhadap sel MCF-7 (Haryanti, 2008). Selain itu, kemungkinan lain ekstrak $H$. corymbosa juga mampu menghambat ekspresi protein c-Myc melalui penghambatan CDK2 yang melindungi degradasi c-Myc melalui jalur proteosom (Haryanti, 2008).

Hasil yang ditunjukkan oleh penelitian ini belum mampu menggambarkan dosis efektif yang dapat digunakan dalam terapi kanker. Perlu adanya penelitian lanjutan baik untuk uji toksisitas, optimasi dosis, maupun uji in vivo dengan menggunakan ekstrak terpurifkasi sehingga dapat diperoleh hasil yang lebih baik dalam penentuan dosis efektif sebelum memasuki uji klinik. Perlu 
juga dilakukan penelitian lanjuta berkaitan dengan pembuatan sediaan farmasi yang siap dikonsumsi.

\section{KESIMPULAN}

Ekstrak etanolik $H$. corymbosa, mengandung asam ursolat, mampu menghambat proliferasi sel melalui regulasi ekspresi protein c-Myc. Ekstrak etanolik $H$. corymbosa mempunyai potensi sebagai agen antiproliferasi sel kanker payudara.

\section{UCAPAN TERIMAKASIH}

Terimaksih untuk DP2M DIKTI yang telah membantu mendanai penelitian ini melalui program PKM 2008.

\section{DAFTAR PUSTAKA}

Amati, B., Alevizopoulos, B.K., dan Vlach, J., 1998, Myc and The Cell Cycle. Biosci 3: 250-268.

Basu, G, D., Pathangey, L.B., Tinder, T.L., Gendler, S.J., and Mukherjee, P. (2004). 'Mechanisms Underlying the Growth Inhibitory Effects of the Cyclo-Oxygenase-2 Inhibitor Celecoxib in Human Breast Cancer Cells', Journal from Breast Cancer Research, 2(11), 632-642.

Haryanti, S., 2008, Aktivitas Sitotoksik Dan Induksi Apoptosis Ekstrak Etanolik Hedyotis Corymbosa L. Pada Sel Kanker Payudara MCF-7, Publikasi Ilmiah. Program Pascasarjana UGM, Yogyakarta.

Hsu, Y-L, Kuo, P-L, and Lin, C.-C., 2004, Proliferative inhibition, cell-cycle dysregulation, and induction of apoptosis by ursolic acid in human non-small cell lung cancer A549 cells. Life sciences, 75(19):23032316.

La Rosa, F.A., Pierce, J.W., dan Shonenshein, G.E., 1994, Differential Regulation of c-Myc Oncogene Promotor by the NF-kB Rel Family of Transcription Factor. Molecular and Cellular Biology. 1039-1044.

Mutiara, U., Embun, S.S.A., Sri, N.O.U., Asmah, R., Ikawati, M., Meiyanto, E., 2008. Kajian Molekuler Senyawa Aktif Ekstrak Etanolik Hedyotis Corymbosa Pada Protein Era Serta Efek Antiproliferasinya
Terhadap Sel Kanker Payudara Tikus Galur Sprague Dawley Terinduksi 7,12 Dimetil Benz(a)Antrasen, Prosiding Kongres Ilmiah Nasional Ikatan Sarjana Farmasi Indonesia XVI. ISBN 978-979-95107-6-2, Penerbit ISFI.

Schimmer, A.D., 2004, Inhibitor of Apoptosis Proteins: Translating Basic Knowledge into Clinical Practice, Review, Cancer Research 64:7183-7190.

Zuhud dan Haryanto, 2004, Pelestarian Pemanfaatan Keanekaragaman Tumbuhan Obat Hutan Tropika Indonesia, Kerjasama Jurusan Konservasi Sumberdaya Hutan, Fakultas Kehutanan IPB dan Lembaga Alam Tropika Indonesia (LATIN). 